Virginia Commonwealth University VCU Scholars Compass

2007

\title{
Mind the Gaps: Exploring the Use of Technology to Facilitate Parental Involvement, Particularly for Historically Underserved Populations
}

Jonathan D. Becker

Virginia Commonwealth University, jbecker@vcu.edu

Follow this and additional works at: http://scholarscompass.vcu.edu/edlp_pubs

Part of the Educational Leadership Commons

Copyright Rowman \& Littlefield Education. All rights reserved. Please contact the publisher for permission to copy, distribute or reprint.

\section{Downloaded from}

http://scholarscompass.vcu.edu/edlp_pubs/7

This Article is brought to you for free and open access by the Dept. of Educational Leadership at VCU Scholars Compass. It has been accepted for inclusion in Educational Leadership Publications by an authorized administrator of VCU Scholars Compass. For more information, please contact libcompass@vcu.edu. 


\title{
Mind the Gaps: Exploring the Use of Technology to Facilitate Parental Involvement, Particularly for Historically Underserved Populations
}

\author{
JONATHAN D. BECKER
}

\begin{abstract}
Decades of research establishes positive associations between parental involvement and a number of important student outcomes, including student achievement. Furthermore, a number of technological innovations make facilitating parental involvement more possible than ever. Those possibilities, however, require varying levels of technological sophistication and infrastructure developments in the homes and communities. That a well-documented digital divide exists between low-income and more-affluent communities means that students and families who live in low-income communities-generally, people of color-can be denied access to opportunities for meaningful involvement in and engagement with the schools. To avoid creating an opportunity gap, school leaders must therefore understand and work with the families and communities whom they serve as they move toward technological facilitation of home-school-community connections.
\end{abstract}

Tate in 2004, the superintendent of the Metropolitan 1 Nashville Public Schools in Tennessee, Dr. Pedro Garcia, undertook an act of community engagement that was equally brave and noteworthy. Garcia invited the entire community to complete a survey to elicit opinions on his job performance. Over 2,000 community residents completed the 
survey, and the results were mixed. Those parents most closely involved with the school system tended to have the most favorable opinions of the superintendent and the district. Those residents least connected to the district reported the least positive opinions (Carr, 2005).

The survey was clearly brave in that few school leaders are willing to collect data about their own performances in such a formal manner. Such a reflective exercise is laudatory but certainly uncommon, particularly among superintendents. The survey was noteworthy, too, but not so much for the content or length. There were 22 short-answer Likert-style questions and 4 open-ended questions. Rather, it was the format of the survey that was so notable. This was not a standard paper-and-pencil survey mailed to residences within the community; instead, this was a web-based survey that was linked to the district's web page but hosted on a local service provider's server (Carr, 2005).

That over 2,000 residents responded to the survey is commendable, but district officials admitted that there were questions about the generalizability of the results. That is, it is not clear that the respondent sample was representative of the community served by the district. In general, with any kind of community questionnaire designed to elicit opinions, those who respond tend to have strong opinions and so are willing to undertake the effort to complete the survey. However, a web-based survey changes that dynamic a bit. For those with an easily accessible Internet-connected computer and for those who are technologically proficient, such a format adds a level of ease to the process. However, for many, a web-based survey is difficult to complete, either for reasons of accessibility or comfort. In Nashville, where almost $12 \%$ of the population lives below the poverty level, it is quite likely that a significant percentage of the residents in the district was rendered voiceless by the process.

In fact, the web-based nature of this survey raises a number of issues and questions about parental involvement and community engagement in the schooling process. Paramount among those issues is whether technologically en- 
hanced means of parental involvement and community engagement utilized by schools and districts will create participation gaps within the community. Or, presented as a question, as advanced technologies are integrated into efforts to engage the community in the affairs of the schools, in light of existing gaps in access to technology, will those who are economically disadvantaged become further disenfranchised?

This article begins to address those issues by first discussing the importance of parent involvement and community engagement in schools. That discussion is followed by some information about and examples of technological innovations that make facilitating parental involvement and community engagement more possible than ever. Subsequent to that is a section about the potential limits of those technologies given the data about the technology access divides that define society. The final section discusses the ramifications of those limitations for schools and districts and includes a set of recommendations for educators and school leaders looking to move to the next generation of parental involvement and community engagement. In this way, the goals for this article are to be informative, encouraging, and cautionary.

\section{The Benefits of Parental involvement}

Decades of research have established positive associations between parental involvement and community engagement and a number of important student outcomes (Callahan, Rademacher, \& Hildreth, 1998; Fan \& Chen, 1999; Griffith, 1996; Henderson \& Mapp, 2002; Portes, Zady, \& Dunham, 1998). According to Henderson and Mapp's synthesis of the research on parental involvement, the benefits of parental involvement include

higher grade point averages and scores on standardized tests or rating scales; enrollment in more challenging academic programs; more classes passed and credits earned; better 
attendance; improved behavior at home and at school; and better social skills and adaptation to school. (p. 30)

Parental involvement has also proven to be particularly beneficial for students from traditionally disadvantaged families and communities. Jeynes's (2003) meta-analysis of 21 studies concluded that, overall, parental involvement is significantly related to academic achievement for all the minority groups under study. For all groups, parental involvement as a whole affected all the academic measures under study by a standard deviation of at least 0.2 . In a study of 307 lowincome ethnic-minority children and their primary caregivers in a large urban school district in the Northeast, McWayne, Hampton, Fantuzzo, Cohen, and Sekino (2004) concluded that "parents who actively promote learning in the home, have direct and regular contact with school, and experience fewer barriers to involvement have children who demonstrate positive engagement with their peers, adults, and learning" (p. 363). Finally, in a federally funded study conducted by Westat and Policy Study Associates (2001), researchers concluded that across the 71 Title I schools under study, students made greater gains when teachers were particularly active in outreach to parents.

The value and importance of parental involvement, particularly for low-income children, was recognized by federal legislators and codified into Section 1118 of the No Child Left Behind Act. The law "includes important requirements for schools, districts and states to organize programs of parental involvement and to communicate with parents and the public about students' achievement and the quality of the schools" (Epstein, 2005, p. 179). Specifically, Section 1118 mandates that all districts and all schools receiving Title I funds have a written parent-involvement policy that must be developed in collaboration with, approved by, and distributed to parents of children in the schools and the community at large. In addition, these schools and districts must build and strengthen their capacity to implement the plan, and they must conduct annual evaluations of their programs that involve parents. No less than $1 \%$ of Title I 
funds must be allocated toward ensuring that these goals are met.

\section{Types of Parental InVolvement}

No Child Left Behind also, for the first time, created a definition of parental involvement within the Elementary and Secondary Education Act. According to Section 9101(32), parental involvement is

the participation of parents in regular, two-way, and meaningful communication involving student academic learning and other school activities, including ensuring

* that parents play an integral role in assisting their child's learning;

* that parents are encouraged to be actively involved in their child's education at school;

* that parents are full partners in their child's education and are included, as appropriate, in decision-making and on advisory committees to assist in the education of their child; and

* that other activities are carried out, such as those described in section 1118 of the Elementary and Secondary Education Act.

That definition, however, is vague at best. A more thorough, and the most common, framework for understanding schoolcommunity-family involvement is the typology offered by Epstein, Coates, Salinas, Sanders, and Simon (1997), which comprises six types of involvement:

Parenting: the basic obligations of families

Communicating: the basic obligations of schools

Volunteering: family involvement at school

Learning at home: family involvement with children on academic activities

Decision making: family participation in school governance and advocacy

Collaborating with the community: exchanges with community organizations 
Alternately, Ho Sui-Chu and Willms (1996) present four basic types of involvement. The two home-based forms discuss school activities and monitor out-of-school activities. The two school-based forms of involvement include contacts with school staff and volunteering and attending parentteacher conferences and other school events. Marcon (1999) makes a distinction between parents who are active and "in charge" (volunteering: class visit, helped with class visit) or passive and "reacting to the school" (communicating: parent-teacher conference, home visit).

However one defines it, advances in technology definitely blur the lines of demarcation between different types of parental involvement. Dynamics of time (synchronicity) and space (geography) are altered. For example, real-time webbased videostreaming renders the distinction between home-based and school-based parental involvement meaningless (Ho Sui-Chu \& Willms, 1996). Also, asynchronous forms of electronic interaction make communications between the school and the home possible virtually anytime, anywhere. Thus, technological progress makes facilitating parental involvement easier and more efficient than ever. The next section discusses some of those innovations.

\section{Technology and Parent Involvement}

In March 1996, Bill Gates wrote a guest editorial in THE Journal about a concept he called connected learning community. This community comes together in three ways: "networked school districts where all the students are connected; connections between homes and schools; and connections reaching out to the entire world . . . everyone accessible on the Internet" (p. 10). This vision involves personal computers connected via the World Wide Web. In 1996, that was fairly revolutionary thinking. Today, however, only a decade after Gates's editorial, advances in technology allow one to think even more globally and more broadly about facilitating parental involvement in schools. 


\section{Electronic Communications}

Most of the innovations and ideas discussed in this section revolve around web-based technologies. In particular, the foundation for all of the possibilities described here is a comprehensive Internet presence by schools and districts. That is to say, schools and districts can engage parents and communities by utilizing the Internet as the hub of the connected learning community. And that Internet presence can be so much more than a set of web pages with information about the district or school. There is a small but growing body of literature on what information and services are offered by schools and districts and what should be offered through their websites (Bradford, Ducan, \& Tarcy, 2000; Miller, Adsit, \& Miller, 2005; Starr, 2002).

However, like the technology itself, even that recent research is quickly becoming obsolete. With next-generation systems, school and district websites can become dynamic and interactive communication centers. An eSchool News (2006) special report discusses a new web-based communication system called Centerpoint, used in the Fairbanks Northstar Borough School District in Fairbanks, Alaska. The system allows parents to check in on any number of aspects of their children's educational experience, including but not limited to test scores, grades, attendance, disciplinary actions, homework assignments, and so on. In addition, there is a feature in the system whereby certain benchmarks automatically trigger electronic messages to parents or caregivers. For instance, if a student is late to class enough times, the system could send a voice message to the child's home, once the data are entered. Or that same message could reach the parent or caregiver in the form of a text message to a cell phone or an e-mail to a wireless handheld device. This system is one of a number of such web-based systems offered by different vendors that allow for an interface between school data systems and parents and community members. 
The hallmark of school and district websites, however, remains the ability for educators to post, and parents to retrieve, important information. The information may range from emergency notices to school lunch menus. In fact, some school and district websites are so cluttered with information that for parents to get the information for which they are searching, it becomes unwieldy and time consuming. Now, however, with technology such as really simple syndication (RSS) software, parents and community members can essentially sign up for or subscribe to the types of information they want. So imagine a community member who does not have any children in the local schools but enjoys seeing school plays or talent shows. If the school or district integrates RSS or some similar web-enabled tool into its own website, that community member can choose to receive only information about the school drama and music departments.

Teachers, parents, and students now have the ability to communicate with one another online through web-based forums hosted by the school or district. Weblogs (or, simply, blogs) offer anyone with Internet access to post his or her writings and allow for reader comments. The newer and more interactive form of blogs are called wikis, which are web applications that allow users to write content but that allow anyone to edit the content by adding to or modifying the existing text. For example, a parent could set up a wiki in advance of an international-theme potluck lunch, whereby parents can post their expected contributions and see what other parents are bringing.

\section{Learning at Home}

Technological innovations make parenting and volunteering less discrete forms of involvement from what Epstein and colleagues (1997) refer to as "learning at home." In fact, the innovations described in this section allow any parent or caregiver to be a more active participant in the schooling process and, thereby, a better parent or caregiver. 
Perhaps, the greatest potential change that technology can bring to the schooling dynamic is that learners no longer need to go to where the teaching is happening. That is to say, all the learning that schools and teachers attempt to facilitate no longer needs to be confined to the bricks-andmortar school buildings during the typical school day. The home-school-home curriculum allows educators to expand the school day and thereby involve parents in the learning process.

An old but reliable medium through which parents could help their children learn is local-access cable television. Many local and regional educational agencies run a localaccess cable television channel that serves as an information center and a teaching and learning center. Important information about education-related events in the community can be broadcast on these channels. Additionally, it is not unusual for these educational agencies to run lessons on these channels, particularly around the time when standardized tests are administered.

Local-access cable television is an older form of technology, and newer forms offer greater possibilities for parents who want to facilitate learning in the home. At the very least, a comprehensive web-based communication system can allow teachers to create a classroom-level website that contains information about assignments and projects. Parents can have access to this information and then monitor the homebound learning of their children. Additionally, a hallmark of a comprehensive school or district website is the inclusion of a set of links to homework-helper websites. There are many valuable (and free!) web-based services where students and parents can go to get help, ranging from message boards to live (real-time) one-to-one chat-based tutors.

One example of an effective and cost-efficient technologyenriched home-school-home curriculum is the Achieve Now! program, offered by Plato Learning (http://www.plato.com). The Achieve Now! program brings together the best in curriculum design and custom animation to a video game console platform. The CD-ROM-based learning adventures, 
which are designed for the Sony PlayStation, use fun characters to engage students in adventures wherein problems are solved through the completion of increasingly complex math and literacy tasks. Numerous evaluation studies document significant achievement growth for students using this program.

The beauty of the PlayStation format is twofold. First, at a fraction of the cost of a personal computer, the PlayStation is an affordable option for schools and families. Second, the PlayStation plugs into a television, which brings about a double benefit. Once the PlayStation with an Achieve Now! CD-ROM is turned on, the ability to watch television shows or play video games that are noneducational at best is defeated. Additionally, televisions are likely to be located in communal parts of the household. Therefore, family members are more likely to become engaged in the program. One of the findings of an evaluation study of the Achieve Now! program was that students with the program became much more likely to work with their parents and siblings (Mann, Shakeshaft, Kottkamp, \& Becker, 2000). In other words, parental involvement in learning at home increased dramatically because of this technology.

In addition to students learning at home is the possibility of parents learning at home. Although some educators believe that it is not the province of local education agencies to deal with parenting issues, a number of districts offer parenting workshops through the schools. Thus, as much as they offer professional development for teachers and administrators, districts that offer parenting workshops might consider delivering them online. The "anywhere, anytime" nature of distance learning is a real advantage to those with busy schedules. Parents, particularly, those who want to be involved in the schooling of their children, are inherently busy. Thus, web-based parenting workshops can add real value to their lives.

Certainly, any good school or district website should include information about volunteering opportunities and a comprehensive list of important contacts. Additionally, the 
website can offer the possibility of putting parent volunteers in touch with other parent volunteers. Also, it is good practice for school or district websites to contain a set of links to parenting resources.

\section{Digital Decision Making}

The web-based survey utilized by the Nashville superintendent described in the introduction is a good example of how technology can be used to involve parents and community members in the decision-making processes of schools and districts. One can certainly imagine school administrators and teachers using online surveys and polls to gather data from parents and community members on important matters, ranging from district policy to pedagogical concerns.

In addition to web-based surveys, advanced technologies such as videoconferencing, webcasts, and Podcasts allow parents to be more included in meetings at which important policy decisions are made. These innovations allow parents to "virtually" attend important meetings at the school or district level. Imagine a single parent of a kindergarten student who has an infant at home. It is not possible for this parent to attend school board meetings face-to-face without asking or hiring someone to watch the house while the children sleep. However, with the implementation of inexpensive and fairly simple webcasting technology, this parent can view the meeting from the comforts of home. Furthermore, if the webcast technology is somewhat sophisticated, this parent may have the ability to post questions to the chat space or simply communicate online with other virtual attendees.

This interactive videoconferencing technology can be expanded to other meetings (e.g., PTA meetings, parent-teacher conferences). And after the meetings are over, Podcasts can be created and stored online for parents to access and listen to on a cell phone, personal digital assistant (PDA), or any other device capable of playing MP3 files (or any other form of audio file used). Now, on the way to work, the busy 
BECKER

parent can listen to, for example, a school board meeting held the previous night.

\section{The Digital Divide: Limitations on Technological Facilitation of Parental InVolvement}

With advances in technology come increased and improved means for schools and districts to involve parents and for parents to get involved in the schooling process. However, those innovations require and assume varying levels of technological sophistication and infrastructure in the homes and communities, and as recent studies show, there are gaps in access to and use of various forms of technology. Therefore, to avoid disenfranchising a segment of the population, it is important for school leaders and educators to consider the demographics of the community and whether technologically facilitated means of improving parental involvement will work. This section examines the current state of the socalled digital divide as a set of potential limits to the use of technology to facilitate parental involvement.

Most of the innovations discussed in the previous section assume that the homes of students have Internet access. Only a few years ago, that meant an Internet-connected personal computer. With the invention of wireless technologies and web-enabled handheld devices, a personal computer is no longer a necessity for accessing the Internet. However, because most families that have access to and use the Internet in the home still do so via the personal computer, it is worth looking at the degree to which computers and the Internet have become a presence in American households.

Using data from the "Computer and Internet Use Supplement" to the October 2003 Current Population Survey, Fairlie (2005) disaggregated computer access and use data by race and income. He found that African Americans and Latinas/Latinos are much less likely to have access to home computers than are White non-Latinos (50.6\% and 48.7\% compared to $74.6 \%$ ) and that those differences are more pro- 
nounced for children than for adults. Using regression models and advanced decomposition techniques, Fairlie concluded that income differences only partly explain computer access gaps. For example, lower levels of income among African Americans account for $27.4 \%$ of the variance in computer ownership between White non-Latina/Latinos and African Americans. "Even among individuals with family incomes of at least $\$ 60,000$, blacks and Latinos are substantially less likely to own a computer or have Internet access at home than are whites" (p. ii). Language is another major predictor of computer ownership. Controlling for education, income, and immigrant status, Fairlie concluded that Spanish-speaking Latina/Latinos, especially Mexican Americans, have extremely low rates of computer ownership.

Mirroring the gaps in computer ownership in U.S. households are the data on Internet access and use. According to A Nation Online, a report released in 2004 by the National Telecommunications and Information Administration, as of October 2003, 54.6\% of U.S. households had Internet access. Disaggregated by race, though, 57\% of African Americans go online, compared with $70 \%$ of Whites. There is also a nearly direct correlation between educational attainment and Internet access. Compared with $61 \%$ of high school graduates and $89 \%$ of college graduates, only $29 \%$ of those who do not have a high school diploma have access to the Internet at home.

The Pew Internet and American Life Project (http://www .pewinternet.org) produces reports on Internet access and use based on regularly administered large-scale daily tracking surveys. Table 1 displays data disaggregated by important demographic characteristics and compiled from two different reports of those surveys (Horrigan, 2006). In addition to information on the percentage of respondents who go online, the data on broadband Internet access are important. Many of the innovations discussed in the prior section assume broadband Internet access. For instance, webcasts and online workshops would not be effective for parents or community members working with a dial-up Internet connection. These data are 
useful, but an important flaw is that the survey was conducted only in English. Thus, households where English is not the primary language are not included in these data. Given Fairlie's (2005) analytic conclusions about the relationship between language and computer access, it is safe to assume the numbers in Table 1 are slightly overstated.

Table 1. Internet Use and Access by Population Demographics [Q: Check income. Did you mean (a) $\$ 30,000-\$ 50,000$ and $\$ 50,001-\$ 75,000$ or (b) $\$ 30,000-\$ 49,999$ and $\$ 50,000-\$ 75,000 ?]$

\begin{tabular}{|c|c|c|c|}
\hline & $\begin{array}{l}\text { Online } \\
(2004)^{a}\end{array}$ & $\begin{array}{c}\text { Broadband } \\
(2005)^{b}\end{array}$ & $\begin{array}{c}\text { Broadband } \\
{ }_{(2006)^{c}}\end{array}$ \\
\hline \multicolumn{4}{|l|}{ Gender } \\
\hline Male & $66 \%$ & $31 \%$ & $45 \%$ \\
\hline Female & 61 & 27 & 38 \\
\hline \multicolumn{4}{|l|}{ Age } \\
\hline $18-29$ & 78 & 38 & 55 \\
\hline $30-49$ & 74 & 36 & 50 \\
\hline $50-64$ & 60 & 27 & 38 \\
\hline $65+$ & 25 & 8 & 13 \\
\hline \multicolumn{4}{|l|}{ Race } \\
\hline White (not Hispanic) & 67 & 31 & 42 \\
\hline Black (not Hispanic) & 43 & 14 & 31 \\
\hline Hispanic (English speaking) & 59 & 28 & 41 \\
\hline \multicolumn{4}{|l|}{ Educational attainment } \\
\hline Less than high school & 32 & 10 & 17 \\
\hline High school grad & 52 & 20 & 31 \\
\hline Some college & 75 & 35 & 47 \\
\hline College + & 88 & 47 & 62 \\
\hline \multicolumn{4}{|l|}{ Household income } \\
\hline Under $\$ 30,000$ & 44 & 15 & 21 \\
\hline$\$ 30,000-\$ 50,000$ & 69 & 27 & 43 \\
\hline$\$ 50,000-\$ 75,000$ & 81 & 35 & 48 \\
\hline Over $\$ 75,000$ & 89 & 57 & 68 \\
\hline \multicolumn{4}{|l|}{ Community type } \\
\hline Urban & 62 & 31 & 44 \\
\hline Suburban & 68 & 33 & 46 \\
\hline Rural & 56 & 18 & 25 \\
\hline
\end{tabular}

Note. Based on Pew Internet and American Life Project data (http://www.pewinternet.org), as compiled by Horrigan (2006).

aFrom the Pew Internet and American Life Project's combined May-June tracking survey of 2,200 adults. bFrom the Pew Internet and American Life Project's combined January-March tracking survey of 4,402 adults.

'From the Pew Internet and American Life Project's February 15 through April 6 survey of 4,001 adults. 
Language issues notwithstanding, an interesting picture of Internet access and use emerges from the data. First, African Americans lag behind Whites in Internet access by a wide margin (43\% versus $67 \%$ ). Second, there is a nearly direct relationship between household income and Internet use and access; the same holds true for educational attainment and Internet use and access. The wealthier and more educated are online to a much greater degree than the poor and less educated Americans. Third, broadband Internet access has not penetrated rural communities much. Only 25\% of survey respondents in rural areas reported broadband Internet access. Finally, there is a nearly direct inverse relationship between age and Internet access and use. Younger adults are online to a much greater degree than older adults. This is an important fact for educators to consider when looking to engage caregivers who may be, for example, grandparents or elderly relatives of the students.

A number of the technological innovations discussed in the previous section assume parental ownership of a wireless handheld device such as a cell phone or a PDA. For example, Podcasts are typically retrieved and listened to through a handheld device such as a PDA or a dedicated MP3 player. Or an emergency broadcast might be conducted by a text message, to be read on a cell phone. Data on ownership of these devices are hard to come by, especially given that the different categories are quickly morphing into multifunction devices.

Difficulties notwithstanding, a survey by the Pew Research Center for the People and the Press (2006) showed that, as of October 2004, 68\% of American adults had cell phones. A slightly more recent survey conducted at the University of Michigan in March 2005 found that 69\% of respondents owned cell phones (University of Michigan, 2006). Of those who reported not owning a cell phone, $11 \%$ reported that someone in their household did. Both of those studies found that $14 \%$ of respondents owned a Palm Pilot or similar PDA.

The 68\% cell phone ownership statistic was up 4\% from the same study conducted 2 years prior, in which income 
was deemed a crucial factor in cell phone ownership. Nearly $90 \%$ of households with an income of $\$ 75,000$ or more had at least one cell phone, compared to $42 \%$ of households with an income less than $\$ 20,000$. However, despite the income variation, African Americans and Latina/Latinos were more likely to report cell phone ownership than were White respondents. Additionally, a study done in the third quarter of 2005 by a group called Telephia showed that African American and Latina/Latinos were the heaviest users of cell phones (Murray, 2006). Thus, the same access and use gaps that exist with respect to computers and the Internet by race do not appear with regard to cell phones.

\section{Conclusion and Recommendations}

In sum, research and practice show that parental involvement is related to positive educational outcomes for children, particularly for those from typically disadvantaged communities. Furthermore, advances in technology make the facilitation of parental involvement easier and greater than ever before. However, technologically enhanced facilitation of parental involvement could unintentionally neglect and perhaps affront segments of the population who lack access to the necessary technology. In fact, the digital divide disfavors people of color, low-income families, and people for whom English is not the primary language-the same individuals and communities who have been historically underserved by the nation's public schools. So the question is, how can we take advantage of these technological innovations without further exacerbating long-standing inequities in educational opportunities?

An answer to that question begins to develop by integrating research-based conclusions about characteristics of effective parental involvement programs and what is particularly effective with minority parents. The three recommendations offered here involve closing the access gap, the cultural gap, and the relationships gap. 


\section{Close the Access Gap: Build a Technological Infrastructure to Facilitate Greater Parental Involvement}

One of the major themes identified by Henderson and Mapp (2002) in their synthesis of the literature on parental involvement is that initiatives are most effective when they are part of an integrated, comprehensive plan to support student achievement. Wang, Oates, and Weishew (1997) write about a "broad-based, school-family-communitylinked coordinated approach" (p. 176). In light of this theme and given what is discussed here about the digital divide, Project LemonLINK in Lemon Grove, California, is an exemplary project.

According to the Project LemonLINK website (http://www .lgsd.k12.ca.us/lemonlink/About.htm), "the heart of the project is the creation of a Connected Learning Community through business and government partnerships to develop a unique infrastructure that connects all schools and the city via microwave, fiber-optic and laser technologies." The project has turned an otherwise small and diverse community outside of San Diego, where the students in the school district struggled to score at or above national averages on standardized test scores, into a lighthouse district. In addition to the wireless network that blankets the entire community, the schools are buried in thin-client computer terminals connected to an unparalleled central data center, from where server-based computing emanates. As students and their families take advantage of the wide-area network, from home or in the schools, the school district serves as the information and communication hub of the community.

Although this may seem like the kind of initiative that only a wealthy community could undertake, Lemon Grove is not such a place. The community is racially diverse, and 69\% of the students served by the school district qualify for free or reduced-price lunch. In fact, Project LemonLINK was envisioned as a way to bridge the digital divide. This connected learning community levels the playing field through funds obtained by the school district and through partnerships 
with corporations and the community. A simple Google search for Project LemonLINK reveals just how much attention this initiative has received in various media sources. And the attention is much deserved. By thinking globally and embracing a philosophy of partnership, the Lemon Grove School District has created the connected learning community of which Bill Gates spoke in 1996. Parents in the community cannot help but be involved as part of this integrated, comprehensive plan to support student achievement and community engagement.

"If you build it, they will come" is the familiar refrain from the popular movie Field of Dreams, but it might also be adopted as a slogan for schools or districts such as Lemon Grove that look to use technology to improve parental involvement and student achievement. Lemon Grove built a wide-area network, and the students and parents came.

Similarly, there are other ways that schools or districts might build supports for technologically enhanced parental involvement. Short of building the sort of full-scale network created in Lemon Grove, districts might consider providing families in need with the technologies to which they lack access. This might take the form of one-to-one computing programs in which each student is provided with a laptop computer, or it might involve providing the neediest households with refurbished computers discarded by the schools or community organizations. Examples of these sorts of programs range from statewide implementation of a laptop program (e.g., Maine's Learning Technology Initiative) to district-level programs (e.g., the Computers for Families program).

Funding for such programs is reasonably ubiquitous, particularly for local education agencies that serve large numbers of low-income children. Federal funding programs such as eRate and the Enhancing Education Through Technology program are specifically intended to benefit the most needy school communities. Additionally, Title I funds can be used to help build a technological infrastructure that will help facilitate greater parental involvement. Finally, there are nu- 
merous smaller grant opportunities earmarked for local education agencies in underserved areas. In essence, lack of funds is not a legitimate excuse for districts that claim that projects such as LemonLINK are unrealistic given the demographics of their community.

\section{Close the Cultural Gap: Use Deracialized and Culturally Responsive Technology}

As with any means of facilitating parental involvement, policies must be examined for cultural and racial biases. Policies must be "more organic and sensitive to an expanded, as opposed to a limited, definition of involvement" (López, 2001, pp. 15-16). In his study of the involvement patterns of immigrant and migrant families in the Texas Rio Grande Valley, López concluded that little formal interaction between the parents and the schools did not mean the parents were not involved. For the families in Lopez's study, involvement meant teaching children the importance of education through the medium of hard work. Children were made to work in the fields and were exposed to the life of limited opportunities that awaited them if they dropped out of school. However, from the schools' perspective, because these parents rarely, if ever, showed up at formal schoolrelated functions, they did not care about education and were not involved in their children's education. As a result, educators and school leaders must, as Crozier (2001) posits, deracialize parental involvement policies.

Such deracialization might involve critical examination of "one size fits all" approaches and recognition of "the roles that ethnic minority parents are playing or the constraints that impede their involvement" (Crozier, 2001, p. 329). Although technology that facilitates parental involvement may not be able to recognize the role that parents do play, there are important ways that technological components can be deracialized. For instance, Gillani (2000) makes a strong argument for culturally responsive educational websites. The 
World Wide Web, Gillani claims, is an ideal means for instructional and informational delivery that, consistent with Vygotsky's sociocognitive theory, is personalized and socially situated. Websites are flexible and customizable tools for delivering instruction and information.

The process of designing a culturally responsive website, according to Gillani (2000), involves four steps: cultural analysis, content organization, actual development, and evaluation. The cultural analysis stage involves getting to know the cultural background of the target population and recognizing web design implications from this. For example, using Shade, Kelly, and Oberg's (1997) notion of cultural characteristics, a local education agency that serves a significant number of African American students might respect and incorporate the cultural aesthetic appreciation of bright colors into the design of a website. Similarly, the content organization phase takes into account the look and feel of the site and the site architecture with respect to the needs and expectations of the student population. Some cultural groups, for example, may value a hierarchical structure, whereas another group might prefer something that is sequential (Gillani, 2000). The development stage follows from there, and the evaluation stage involves checking in with students, parents, and community members about factors such as ease of use and missing elements.

In addition to a culturally responsive website, electronic communications should be, to the extent possible, translated into the home languages of families served by schools and districts, much as print communications are. In the 2003-2004 academic year, the Delta/Greely School District in Delta Junction, Alaska, began an initiative called Project Parent Connect (Barton, 2002). Initially funded by a federal Enhancing Education Through Technology grant, the project had two main components: the implementation of a webbased student information system and the use of Russianlanguage translation software. One-third of the students in the 844-student district came to the district from the Ukraine, Moldavia, Romania, and Russia. Therefore, to in- 
crease parental involvement and improve student achievement, the information system and the translation software were integrated so that the Slavic families could monitor the students' performance and freely communicate with teachers. Additionally, families without home computersparticularly, those who qualified for free or reduced-price lunch-were allowed to borrow computers from the district (Barton, 2002). Project Parent Connect is a wonderful example of the use of technology to engage parents who might otherwise have been excluded from the schooling process.

\section{Close the Relationship Gap: Build Connections and Social Capital With Technology}

Another one of the major themes identified by Henderson and Mapp (2002) in their synthesis of the literature on parental involvement is that successful programs are keenly focused on relationship building: "When programs and initiatives focus on building respectful and trusting relationships among school staff, families, and community members, they are effective in creating and sustaining family and community connections with schools" (p. 43). In fact, the third recommendation that flows from their synthesis of the research is to "work with families to build their social and political connections" (p. 63). Projects such as LemonLINK and Project Parent Connect help parents to make such connections, but there are simpler ways that technology can be used toward the same effect.

In particular, the ability of parents to communicate electronically with teachers and administrators is important but not entirely sufficient. A number of researchers and scholars have written about the community-building potential of computer-mediated communications (Becker, 2004; Etzioni \& Etzioni, 1999; Rheingold, 1993). "The Internet as an embodiment of multiple forms of computer-mediated communications is a notably communal space imbued with . . . properties that correlate with necessary attributes of the 
very notion of "community" (Becker, 2004, p. 190). Thus, local education agencies should consider web-based technologies that provide opportunities for families to connect with each other electronically.

Message boards are one example of a web-based technology that allows people to communicate with one another asynchronously. For example, parents can use a web-based message board to coordinate carpools to and from after-school activities. Real-time computer-mediated communications such as chat rooms might benefit parents who are looking for immediate assistance, advice, or simply an opportunity to "talk" with other parents. Additionally, if a school is organizing an international potluck meal, for instance, parents might benefit from a dedicated wiki where they can collaboratively and asynchronously coordinate who is providing which foods and supplies. These are all simple technologies that can go a long way toward building social connections and a real sense of community between and among families and schools.

In sum, this article is meant to be informative yet cautionary. That is, it is clear that genuine parental involvement in schools yields real benefits to the nation's youth and that schools have available to them wonderful technological means that can facilitate increased levels of involvement. And although there are real gaps by race and socioeconomic status in access to and use of various forms of technology, there are plenty of examples of technologically enhanced parental involvement initiatives across the country in places where students are otherwise disadvantaged. Still, however, educators must mind those gaps as well as cultural and social gaps so as to not further disenfranchise entire populations that have been historically underserved by the nation's schools. JSPR

\section{REFERENCES}

Barton, R. (2002). Family connections. Northwest Education, 10(2). Retrieved August 27, 2006, from http://www.nwrel.org/ nwedu/10-02/family/ 
Becker, J. D. (2004). Thinking outside the (bricks-and-mortar) box(es): Using cyberspace technology to reconceptualize schooling and community in the face of resegregation. Journal of School Public Relations, 25, 177-202.

Bradford, R., Duncan, J., \& Tarcy, B. (2000). Simplified strategic planning: A no-nonsense guide for busy people who want results fast! Worcester, MA: Chandler House Press.

Callahan, K., Rademacher J. A., \& Hildreth, B. L. (1998). The effect of parent participation in strategies to improve the homework performance of students who are at risk. Remedial and Special Education, 19, 131-141.

Carr, N. (2005). Is your superintendent making the grade? Nashville parents share input via online survey. eSchool News. Retrieved September 1, 2005, from http://www.eschoolnews .com/news/showStory.cfm?ArticleID=5437

Crozier, G. (2001). Excluded parents: The deracialisation of parental involvement. Race, Ethnicity, and Education, 4, 329341.

Epstein, J. L. (2005). Attainable goals? The spirit and letter of the No Child Left Behind Act on parental involvement. Sociology of Education, 78, 179-182.

Epstein, J. L., Coates, L., Salinas, K. C., Sanders, M. G., \& Simon, B. S. (1997). School, family, and community partnerships: Your handbook for action. Thousand Oaks, CA: Corwin Press.

eSchool News. (2006, April 5). Automatic email alerts keep parents well informed: Next-generation student and school data system offers advanced communication features. Retrieved August 18, 2006, from http://www.eschoolnews.com/news/showStorysr .cfm?ArticleID=6230

Etzioni, A., \& Etzioni, O. (1999). Face-to-face and computermediated communities, a comparative analysis. Information Society, 15, 241-248.

Fairlie, R. W. (2005). Are we really a nation online? Ethnic and racial disparities in access to technology and their consequences. Report for the Leadership Conference on Civil Rights Education Fund. Retrieved August 14, 2006, from http://www.freepress .net/docs/lccrdigitaldivide.pdf

Fan, X., \& Chen, M. (1999). Parental involvement and students' academic achievement: A meta-analysis. Arlington, VA: National 
Science Foundation, National Center for Education Statistics. (ERIC Document Reproduction Service No. ED430048)

Gates, B. (1995). The connected learning community: Using technology for education. THE Journal, 23(8), 10.

Gillani, B. B. (2000). Culturally responsive web sites. Media and Information Technologies, 37, 185-195.

Griffith, J. (1996). Relation of parental involvement, empowerment, and school traits to student academic performance. Journal of Educational Research, 90, 33.

Henderson, A. T., \& Mapp, K. L. (2002). A new wave of evidence: The impact of school, family, and community connections on student achievement. Austin, TX: Southwest Educational Development Laboratory.

Horrigan, J. (2006, May 28). Home broadband adoption is going mainstream and that means user-generated content is coming from all kinds of Internet users. Retrieved August 15, 2006, from http://www.pewinternet.org/pdfs/PIP_Broadband_trends2006 .pdf

Ho Sui-Chu, E., \& Willms, J. D. (1996). Effects of parental involvement on eighth grade achievement. Sociology of Education, 69, 126-141. (ERIC Document Reproduction Service No. EJ533315)

Jeynes, W. H. (2003). A meta-analysis-The effects of parental involvement on minority children's academic achievement. Education and Urban Society, 35, 202-218.

López, G. R. (2001, April). On whose terms? Understanding involvement through the eyes of migrant parents. Paper presented at the annual meeting of the American Educational Research Association, Seattle, WA.

Mann, D., Shakeshaft, C., Kottkamp, R., \& Becker, J. D. (2000). Playing to learn. Electronic School. Retrieved September 11, 2006, from http://www.electronic-school.com/2000/09/0900f4 .html

Marcon, R. A. (1999). Positive relationships between parent school involvement and public school inner-city preschoolers' development and academic performance. School Psychology Review, 28, 395-412.

McWayne, C., Hampton, V., Fantuzzo, J., Cohen, H. L., \& Sekino, Y. (2004). A multivariate examination of parent involvement and 
the social and academic competencies of urban kindergarten children. Psychology in Schools, 41, 363-377.

Miller, S., Adsit, K., \& Miller, T. (2005). Evaluating the importance of common concepts in school-based websites: Frequency of appearance and stakeholders' judged value. Curriculum Leadership, 49(6), 34-40.

Murray, R. (2006, January 17). Survey tracks ethnic mobile usage. Wireless Week. Retrieved August 30, 2006, from http://www .wirelessweek.com/article/CA6299882.html

National Telecommunications and Information Administration. (2004). A nation online: Entering the broadband age. Retrieved August 20, 2006, from http://www.ntia.doc.gov/reports/anol/ NationOnlineBroadband04.htm

Pew Research Center for the People and the Press. (2006). National polls not undermined by growing cell-only population: The cell phone challenge to survey research. Retrieved March 28, 2007, from http://people-press.org/reports/pdf/276.pdf

Portes, P. R., Zady, M. F., \& Dunham, R. M. (1998). The effect of parents' assistance on middle school students' problemsolving and achievement. Journal of Genetic Psychology, 159, 163-179.

Rheingold, H. (1993). The virtual community: Homesteading on the electronic frontier. Reading, MA: Addison-Wesley.

Shade, B. J., Kelly, C., \& Oberg, M. (1997). Creating culturally responsive classrooms. Washington, DC: American Psychological Association.

Starr, L. (2002). Share the pride: Create a school website. Education World. Retrieved August 11, 2006, from http://www.education-world.com/a_tech/tech014.shtml

University of Michigan, Department of Communication Studies. (2006, May). On the move: The role of cellular communications in American life. Retrieved September 1, 2006, from http:// 141.211.177.75/UofM/Content/comm/document/OnTheMove .pdf

Wang, M. C., Oates, J., \& Weishew, N. L. (1997). Effective school responses to student diversity in inner-city schools: A coordinated approach. In G. D. Hartel \& M. C. Wang (Eds.), Coordination, cooperation, collaboration (pp. 175-197). Philadelphia, PA: Mid-Atlantic Regional Educational Laboratory at Temple University. 
Westat and Policy Studies Associates. (2001). The longitudinal evaluation of school change and performance in Title I schools. Washington, DC: U.S. Department of Education, Office of the Deputy Secretary, Planning and Evaluation Service. Retrieved March 6, 2007, from http://www.ed.gov/offices/OUS/PES/esed/lescp_ highlights.html

Jonathan D. Becker is an assistant professor in the Foundations, Leadership, and Policy Studies Department of the School of Education and Allied Human Services at Hofstra University. Dr. Becker teaches courses in the politics of education, the social and legal contexts of education, and educational research methods. His research agenda includes continued study of digital equity in education, educational equity as a multilevel organizational phenomenon, and the intersection between educational leadership and educational technology. Dr. Becker is also the director of the doctoral program in educational leadership and policy studies. Please address correspondence to Jonathan D. Becker, JD, PhD, Assistant Professor, Department of Foundations, Leadership, and Policy Studies, School of Education and Allied Human Services, Hofstra University, Hempstead, NY 11549-1270. E-mail: Jonathan.d.becker@hofstra.edu. 